\title{
MEMBAYANGKAN INDONESIA DARI NOVEL-NOVEL ANTARETNIS DAN ANTARAGAMA \\ PERIODE 1920-AN HINGGA 1970-AN
}

\author{
IMAGINE INDONESIA FROM INTERETHNIC \\ AND INTERRELIGIOUS NOVELS PERIOD 1920'S TO 1970'S
}

\author{
Dwi Rahariyoso \\ Jalan Cipto Mangun Kusumo 59, Ponorogo, Jawa Timur \\ Pos-el: jaketlusuh@gmail.com \\ Telepon 085643728390
}

\begin{abstract}
Abstrak
Penelitian ini menguraikan persoalan perkawinan antaretnis dan antaragama yang terdapat dalam novel Indonesia periode 1920-an hingga 1970-an. Pengelompokan kategori novel berdasarkan genre yang terdapat dalam novel-novel yang mempunyai kapasitas dalam membahas tema perkawinan antaretnis dan antaragama. Melalui genre yang dimunculkan dalam novel, pola dan bentuk struktur penceritaan bisa dicermati secara saksama. Kategori antaretnis dan antaragama dalam novel periode 1920-an hingga 1970-an mengindikasikan bahwa kesadaran tentang multikulturalisme, pluralitas, dan kebangsaan sebagai sebuah gagasan penting bagi jati diri bangsa Indonesia. Semangat kebangsaan yang penuh kebhinekaan telah menjadi isu sentral yang dikembangkan oleh pengarang pada periode tersebut melalui kisah-kisah percintaan (roman) kaum muda dalam novel Indonesia modern.
\end{abstract}

Kata kunci: antaretnis, antaragama, genre, pola, roman, kebangsaan, pluralitas, multikulturalisme, toleransi, Indonesia

\begin{abstract}
Husband research outlines the issue of inter-ethnic and inter-religious marriages are hearts novel Indonesia the 1920's period until 1970's. Novel category grouping by genre what are hearts novel-novel that had the capacity hearts discuss the theme of interethnic and inter-religious marriages. The hearts raised through a new genre, patterns and The narrative structure can be observed carefully. Category interethnic and interreligious new hearts 1920's period until 1970's indicated that awareness about multiculturalism, pluralism, and nationality AS an idea essentials personal identity of the Indonesian nation. The full diversity of the national spirit already a central issues in developed posted author that period through the storys of romance (romance) youth hearts modern Indonesian novel.
\end{abstract}

Keywords: interethnic, interreligious, genre, pattern, romance, nationality, pluralism, multiculturalism, tolerance, Indonesia

\section{Pendahuluan}

Kesusastraan Indonesia modern dimulai dengan adanya kesadaran dari para pengarang terhadap konsep kebangsaan. Semangat kebangsaan yang hadir pada periode tahun 1930-an menjadi satu pemantik dalam melihat keberlangsungan komunitas masyarakat Indonesia awal. Nasionalisme sebagai kesadaran dan wacana kesatuan didukung dengan penggunaan bahasa yang menjadi satu simbol kebangsaan, yaitu pada masa itu dengan menggunakan bahasa Melayu. Bahasa Melayu menjadi satu aspek yang penting dalam menyadari perbedaan antara pribumi dan penjajah. Hingga pada akhirnya bahasa 
Indonesia lahir dari bahasa Melayu dan diakui secara utuh sebagai bahasa pemersatu.

Jika ditinjau lebih detail, bahasa menjadi satu aspek penting yang turut melahirkan kesadaran komunikasi dan juga kecenderungan pola pikir masyarakat pemakainya. Termasuk di dalam konteks tersebut adalah bahasa yang digunakan dalam ranah karya sastra Indonesia, terutama sastra Indonesia modern. Konsep tersebut menjadi satu penghubung secara lebih umum dalam rangka mengetahui lebih banyak tentang masyarakat Indonesia, pluralitas, dan berbagai permasalahan di dalamnya. Asumsi tersebut menjadi penting jika melihat keterkaitan antara kondisi sosial masyarakat secara fenomena dan perjalanan kesusastraan Indonesia dari waktu ke waktu. Sejak kemunculan angkatan Pujangga Baru yang dijiwai oleh Sutan Takdir Alisjahbana hingga karya-karya sastrawan mutakhir pascareformasi, novel Indonesia diwarnai berbagai bentuk pola, tema, karakter, isu dan juga genre kesastraan yang dinamis.

Roman atau novel Indonesia banyak bersinggungan dengan berbagai fakta dan latar belakang sosial masyarakat yang menjadi bagian tematis dalam melihat aspek kebangsaan. Pembinaan rasa kebangsaan dari berbagai perspektif secara umum sangat kompleks, misalnya saja relasi antaretnis dan antaragama. Kedua aspek "tema" tersebut bisa dilihat sebagai sebuah isu yang selama ini jarang diulas atau muncul dalam khazanah kesastraan Indonesia. Pemilihan kedua aspek tersebut dalam penelitian sederhana ini lebih kepada ketertarikan penulis melihat kecenderungan fenonema disintegrasi, permusuhan, maupun persinggungan sosialkultural yang sering terjadi di masyarakat sebagai wilayah yang sensitif. Asumsi tersebut menjadi langkah awal untuk meneliti berbagai relasi dalam novel atau roman Indonesia untuk menemukan bentuk dalam pola-pola genre yang ada, serta melihat isu keIndonesiaan secara lebih luas.

Dalam penelitian sederhana ini akan dibahas genre yang muncul dalam novelnovel Indonesia modern. Fokus kajian hanya dibatasi pada novel periode Balai Pustaka yang mempunyai keterkaitan dengan isu antaretnis dan antaragama. Relasi antaretnis tersebut, misalnya terdapat pada novel Darah Muda (1927) dan Asmara Jaya (1928) karangan Adinegoro, Merantau ke Deli (1940) dan juga novel Tenggelamnya Kapal van Der Wijck (1938) karangan Hamka. Relasi antaragama dalam karya novel Indonesia lebih sedikit dibandingkan dengan novel antaretnis. Kondisi tersebut merupakan sebuah fenomena yang sebenarnya menarik untuk dikaji. Namun, penelitian ini tidak akan mengarah pada aspek tersebut. Novel antaragama yang ada dan sangat populer adalah Keluarga Permana karangan Ramadhan K.H. (1978) dan satu lagi adalah novel Orang Buangan karya Hariyadi S. Hartowardoyo (1971). Novel-novel tersebut akan dianalisis dalam rangka melihat formula yang dominan dan juga jenis genre yang muncul di dalamnya. Analisis sederhana dari struktur (konstruksi) formula tersebut diharapkan mampu digunakan untuk menemukan komposisi dan perubahan bentuk yang terjadi dalam polapola yang digunakan pengarang pada novel dengan isu antaretnis dan antaragama.

\section{Teori Genre}

Kata genre berasal dari bahasa Perancis yang berarti jenis atau kelas (Adi, 2011:195). Sesuai dengan pernyataan tersebut genre sudah digunakan sebagai konsep dalam menentukan tipe atau jenis karya sastra. Dalam kesusastraan, Aristoteles sudah mengategorikan puisi ke dalam berbagai kategori, yaitu epik, lirik, tragedi, dan sebagainya. Asumsi umum genre dipahami sebagai klasifikasi terhadap berbagai bentuk yang lahir dalam sebuah karya sastra, misalnya puisi, prosa, dan drama sehingga apa yang dipahami tentang genre dalam karya sastra masih sebatas kepada pemahaman umum dalam tiga jenis tersebut. Perumusan genre berpijak pada konsep strukturalisme yang melihat teks sebagai sebuah relasi atau hubungan-hubungan struktur antara satu elemen dan elemen lain sehingga teks tersebut membentuk kesatuan yang padu, otonom, dan bisa diterima sebagai sebuah konstruksi karya. 
Dalam perkembangannya, genre sudah mengalami bermacam perluasan, baik variasi maupun penentuan genre. Kondisi tersebut diakibatkan oleh berbagai macam faktor yang ada dalam sebuah struktur teks sastra. Pertimbangan penentuan genre bisa dilihat dari faktor tema, tokoh, metode penceritaan, dan lain sebagainya. Wellek dan Werren mengatakan genre adalah pengelompokan karya-karya sastra secara teoretis berdasarkan pada bentuk luar (majas atau struktur khusus) dan bentuk dalam (sikap, nada, tujuan, subyek, dan audiens) (dalam Adi, 2011:196). Semua studi kritik sastra dan penilaian karya sastra pasti menyangkut pembahasan tentang struktur-struktur semacam

itu.

Pengelompokan genre dibedakan antara genre puisi dan genre prosa (novel) karena secara bentuk strukturnya berlainan. Prosa dikelompokkan lagi menjadi prosa fiksi dan prosa nyata. Meskipun dalam asumsi ini terjadi ambiguitas, yaitu dalam prosa nyata pun sering terkandung unsur yang fiktif. Prosa fiksi atau naratif dibagi lagi menjadi fiksi kanon dan fiksi populer (Adi, 2011:196). Fiksi kanon biasa disebut juga dengan fiksi serius, sedangkan fiksi populer disebut dengan fiksi hiburan.

Aristoteles dan Horace memberikan dasar klasik untuk perkembangan genre menjadi dua jenis utama sastra, yakni tragedi dan epik (Wellek dan Werren, 1995:300). Namun, dalam perkembangannya, teori modern cederung mengesampingkan perbedaan prosapuisi, lalu membagi sastra-rekaan menjadi fiksi (novel, cerpen, epik), drama (dalam prosa maupun puisi), dan puisi (puisi dalam arti yang sama dengan konsep klasik tentang "puisi lirik") (Wellek dan Warren, 1995:300).

Dalam kenyataannya pengelompokan genre itu mudah diambil, tetapi sulit untuk dijelaskan atau didefinisikan. Kondisi tersebut sebenarnya merupakan satu bagian yang dipahami sebagai sebuah konsep yang dinamis (berlangsung) secara terus-menerus dalam dalam pengertian karya sastra. Penggunaan genre membutuhkan pemahaman logis dari kerja film, hal tersebut sebaliknya membutuhkan asumsi-asumsi dalam konteks sosiologis dan psikologis dan membentuk genre yang eksplisit (Adi, 2011:196). Istilah genre lebih sering muncul dalam kritik fiksi populer daripada fiksi serius. Meskipun banyak dibicarakan dan diteliti, kesepakatan tentang arti genre lebih sedikit dibandingkan dengan pertentangannya, karena sifat genre sering berubah.

Genre sangat tergantung dengan berbagai aspek yang melekat pada narasi dan struktur yang ada dalam teks. Kondisi tersebut juga dipengaruhi oleh audiens (pembaca) yang berinteraksi langsung dengan teks sastra. Dalam fiksi populer genre ditentukan berdasarkan kefleksibelan penonton atau pembaca, seperti yang dikatakan Tudor (dalam Adi, 2011:197), bahwa genre adalah apa yang secara kolektif dipercayai orang (audiens). Jadi, genre dalam fiksi populer tidak sepenuhnya sama dengan fiksi serius karena penentuan genre dalam karya sastra sangat tergantung pada narasinya.

Cawellti (dalam Adi, 2011:198) mengategorikan fiksi populer menurut tema dan formulanya, misalnya genre adventure (petualangan), romance (kisah percintaan), alien being (makhluk asing), misteri, dan melodrama sehingga tampak sebagai genre yang sudah mapan. Dalam konsep tersebut Cawellti merumuskan bahwa genre adalah klasifikasi yang muncul berdasarkan dengan isi cerita (narasi) di dalam teks karya. Selain Cawellti yang mendeskripsikan konsep genre, Stam (dalam Adi, 2011:198) mengategorikan cerita dalam teks sastra dengan genre yang bermacam. Stam mengategorikan genre atas dasar konsep yang telah ada dalam sastra, seperti komedi dan melodrama, berdasarkan pada tingkat penjualan, berdasar pada status artistiknya, atau berdasar orientasi seksual.

Kemunculan berbagai konsep dan klasifikasi genre dalam suatu karya sangat dipengaruhi oleh formula yang ada dalam karya tersebut. Formula-formula yang menyusun suatu teks dalam karya sastra menentukan aspek yang dominan dan menonjol untuk penentuan genre. Satu genre bisa tumpang tindih dengan genre lain, khususnya apabila cerita dicampur dengan unsur-unsur yang berbeda. Ada kemungkinan penggabungan atau pencampuran tersebut 
menggabungkan dua unsur yang berlainan, misalkan musik dan komedi dengan unsur drama atau percintaan. Salah satu contoh adalah jika suatu karya di dalamnya muncul unsur percintaan dan laga, bisa dikategorikan sebagai roman dan juga bisa diaktegorikan sebagai petualangan. Konsep tersebut merupakan sebuah komposisi yang muncul dalam melihat kecenderungan genre dalam sudut pandang dan analisis pembaca.

Genre dalam fiksi populer terutama biasanya dimaksudkan untuk memberi informasi tentang gambaran umum yang akan dibaca atau ditonton oleh pembaca atau penonton, dan penentuannya tergantung pada ruang dan waktu (Adi, 2011:199). Dalam novel Indonesia, misalnya, jenis novel yang ceritanya diambil berdasarkan kejadian sejarah, yakni novel Surapati karya Abdul Muis dan Hulubalang Raja karya Nun Sutan Iskandar, bisa dikatakan sebagai novel bergenre sejarah. Kondisi tersebut disimpulkan dari unsur sejarah yang muncul sebagai latar dalam teks tersebut. Selain itu, juga klasifikasi genre sejarah mencakup aspek yang ada sebagai bagian yang membahas realitas historis, ruang dan waktu yang kontekstual dengan tokoh maupun sosok sebagai tema utama cerita.

Definisi konvensional genre cenderung berdasarkan pada konvensi unsurunsur teks fiksi seperti tema dan latar. Karena tema, latar, dan unsur-unsur lain dalam fiksi bervariasi, penentuan genre kadang menjadi membingungkan. Seperti yang disampaikan oleh Tasker (dalam Adi, 2011:200), pada kenyataannya genre merupakan kategori yang bergerak dan tidak dapat digambarkan dalam konteks industri yang selalu mengembangkan, mengubah istilah dari naratif populer. Sementara itu, menurut Ryall (dalam Adi, 2011:200), asumsi umum dalam kritik genre adalah karya seni dan komunikasi muncul dari dan berada dalam konteks sosial, tetapi arti dan maknanya tergantung serta terikat pada konteksnya. Jadi, genre diciptakan melalui dialog antara kesamaan dan perbedaan formula dari banyak fiksi. Penonton atau pembaca yang akan menentukan suatu genre berdasarkan dari unsur atau formula yang terkandung di dalam teks tersebut.

Dalam menentukan genre, peneliti biasanya melihat kesamaan cerita dari berbagai jenis cerita sejenis dan menetukan formula yang menunjukkan kesamaan dan perbedaan sehingga bisa dilihat jenis atau genrenya. Pengulangan suatu jenis fiksi dengan ciri-cirinya yang berlangsung secara konsisten dan kemudian dikenali oleh pembaca atau penonton, maka fiksi dengan ciri-ciri tersebut dapat dikategorikan menjadi penentu genre dalam teks tersebut (Adi, 2011:203). Selanjutnya, berdasarkan ciri dan penjelasan teoretis di atas, beberapa karya novel yang disajikan dalam penelitian ini akan dilihat kecenderungan genre yang muncul dalam unsur-unsurnya, serta perkembangan genre dalam beberapa periode kesusastraan Indonesia. Genre yang muncul akan dilihat aspek-aspek naratifnya secara umum, dalam rangka melihat kecenderungan unsur formulanya maupun variasi dalam karya novel tersebut.

\section{Pembahasan}

Karya novel yang disajikan dalam kurun waktu yang berlainan secara periodik merupakan sebuah usaha dalam rangka melihat kontinyuitas maupun perkembangan umum novel dalam kesastraan Indonesia modern. Meskipun demikian, disadari bahwa apa yang ditampilkan dalam penelitian sederhana ini masih sebatas sampel indikator dan belum menjawab keseluruhan konteks historis perkembangan genre dan formula karya sastra. Keseluruhan novel yang diangkat dalam pembahasan penelitian ini mempunyai keselarasan konsep yang sama, yaitu bergenre roman (kisah percintaan). Istilah roman berasal dari bahasa Inggris romance yang berarti percintaan atau kisah percintaan. Keenam novel dari periode 1930an hingga periode 1970-an akhir, yang diambil sebagai objek penelitian secara umum isinya menceritakan tentang kisah percintaan sepasang manusia. Hal tersebut bisa disimpulkan dari hubungan perkawinan antara pasangan Nurdin dan Rukmini dalam novel Darah Muda; antara Rustam dan Dirsina 
dalam novel Asmara Jaya; antara pasangan Leman dan Poinem dalam Merantau ke Deli; antara Zainudin dan Hayati dalam Tenggelamnya Kapal Van der Wijck; antara pasangan Tantri dan Hiang Nio dalam Orang Buangan; dan antara pasangan Ida dan Sumarto dalam novel Keluarga Permana. Kesamaan konsep isi formula tersebut menjadi satu faktor penghubung dalam menganalisis secara lebih spesifik, terkait dengan kondisi struktur maupun tematisnya.

Pembahasan akan dimulai dari periode awal novel Indonesia modern, yaitu pada periode 1920-an akhir. Pada periode ini penulis menyajikan novel Darah Muda (1927) dan Asmara Jaya (1928) karya Adinegoro. Kedua novel ini diangkat sebagai pembahasan awal karena di dalamnya muncul hubungan perkawinan antara pasangan yang berlainan etnis (suku). Formula tersebut menjadi satu faktor yang menarik dianalisis ketika melihat relasi etnisitas dalam struktur cerita karya sastra. Berikut sinopsis kedua novel tersebut.

Darah Muda menceritakan kisah tentang seorang dokter muda bernama Nurdin yang akan pulang ke Padang menemui orang tuanya. Di kapal, ia berkenalan dengan Rukmini, seorang guru yang pada waktu itu akan berlibur ke Bengkulu. Pertemuan yang sekilas di kapal tersebut rupanya cukup menentukan jalan hidup dokter Nurdin. Sejak saat itu rupanya gadis tersebut terpatri dalam sanubari Nurdin sehingga maksud ibunya hendak mengawinkannya ditolaknya. Selanjutnya, atas pertolongan (nasihat) Nurdin, Rukmini diterima menjadi guru di salah satu perguruan partikelir di Padang. Mamak (paman) Nurdin mempunyai anak gadis, yang menurut adat kebiasaan Minangkabau kalau Nurdin mau, gadis itu akan dinikahkan dengannya. Dalam hal ini, budaya Minangkabau adalah matrilineal sehingga pihak perempuanlah yang melamar pihak lelaki.

Terjadi perdebatan antara Nurdin dan mamaknya tentang perkawinan, tentang poligami, dan tentang adat perkawinan yang biasa terjadi di Minangkabau. Sebenarnya, orang tua Nurdin berkenan menerima Rukmini menjadi menantunya, tetapi karena tradisi adat yang berlainan, terjadi salah paham. Mengapa gadis itu (Rukmini) tiada mau merendahkan diri untuk menjemput Nurdin? Kondisi tersebut merupakan suatu hal yang ganjil bertolak belakang dengan kebiasaan tradisi yang terjadi dalam sistem budaya Minangkabau. Terlihat perbedaan sikap akibat perbedaan kebiasaan adat: di Minangkabau, sudah menjadi adat bahwa perempuan yang menyampaikan pinangan atau yang menjemput laki-laki. Rukmini sebagai gadis Priangan (Sunda), merasa sebaliknya. Ia berharap Nurdinlah yang harus terlebih dahulu datang meminangnya karena begitulah adat yang ada di kampung halamannya. Selanjutnya, Rukmini mendengar kabar bahwa Nurdin akan dikawinkan dengan anak mamaknya yang akan kembali dari Jakarta.

Pada suatu waktu ketika Nurdin mengobati Harun, dilihatnya potret Rukmini di samping tempat tidur anak muda itu. Rupanya Harun dengan sengaja melakukan itu dan berniat membuat Nurdin cemburu. Harun telah mencoba menyampaikan lamaran kepada orang tua Rukmini. Rupanya Nurdin cemburu dan segera menjauhkan diri dari gadis itu. Baik Rukmini maupun Nurdin keduanya menunggu. Singkat kata, Ibu Nurdin meninggal dunia karena sedih memikirkan anaknya yang menjauhkan diri darinya. Sebelum menghabiskan nafas terakhirnya, orang tua tersebut mengakui kesalahan karena hendak mencoba menceraikan hubungan Rukmini dengan Nurdin. Ibu Nurdin mencoba menikahkan Nurdin dengan anak mamaknya yang pulang dari Jakarta. Akhirnya, Nurdin paham duduk perkaranya, ia menyesalkan tindakannya menjauh dari Rukmini selama ini hingga membuat Rukmini jatuh sakit. Kemudian ia meminta maaf kepada Rukmini dan mengetahui bagaimana perasaan cinta Rukmini kepadanya melalui catatancatatannya. Setelah gadis itu sembuh, ia menikah dengan Rukmini.

Dari sinopsis singkat di atas bisa dirumuskan bahwa ada kisah percintaan yang muncul sebagai formula yang mendukung struktur novel. Konstruksi formula yang 
muncul dalam cerita Darah Muda menunjukkan adanya aspek percintaan sepasang manusia dengan latar budaya yang berlainan, yaitu budaya Minangkabau dan budaya Sunda dari kedua tokoh pasangan utama. Unsur kisah percintaan masuk dalam genre roman yang dibumbui dengan formula etnisitas sebagai isu utama yang diangkat pengarangnya. Secara alur, percintaan sepasang manusia tersebut mengalami pasang surut, tetapi pada akhirnya berakhir bahagia (happy ending). Latar belakang kesukuan yang digambarkan dalam cerita tersebut merupakan sebuah dinamika dalam mengembangkan konsep roman (percintaan) dalam novel Indonesia modern sebagai sebuah isu ke-Indonesia-an. Cinta menembus sekatsekat etnisitas maupun budaya, dan pengarang berpihak pada peleburan esensi yang universal, yaitu dengan melepaskan aspekaspek yang dianggap menjadi kendala bagi kedua pasangan tersebut.

Formulasi yang muncul secara menyeluruh ditunjukkan melalui struktur instrinsik karya, yaitu hubungan sepasang manusia, latar sosial budaya, konflik atau rintangan, representasi tokoh-tokoh, watak, tema dan juga penyelesaian atau akhir yang bahagia. Unsur-unsur tersebut merupakan formula yang menjadi satu asumsi sederhana dalam melihat genre dan merumuskan jenis genre tersebut dalam karya sastra.

Novel berikutnya adalah Asmara Jaya yang juga merupakan karya Adinegoro. Secara umum tema novel ini hampir sama dengan novel sebelumnya, yaitu menceritakan kisah perkawinan pemuda Minangkabau dengan gadis Priangan (Sunda). Berbeda dengan perkawinan antaretnis dalam Darah Muda yang mengambil latar di Bukittinggi, latar peristiwa dalam novel ini terjadi di Bandung.

Novel ini menceritakan Rustam seorang pegawai administrasi di Bandung yang telah menikah dengan gadis Sunda bernama Darsina, dan sudah mempunyai anak yang bernama Dirhamsyah. Rustam pemuda Minang, sedangkan Darsina gadis Sunda. Orang tua Rustam yang mengetahui anaknya telah menikahi gadis Sunda datang ke Jawa, kemudian memaksa anaknya untuk menandatangani surat kuasa (surat wakil) persetujuan atau pernyataan karena ia akan dikawinkan dengan seorang gadis di kampungnya. Pada akhirnya, Rustam menandatangani surat pernyataan tersebut meskipun dia sangat mencintai istrinya, Darsina. Hal tersebut merupakan kelemahan dari sosok Rustam. Bapak Rustam pulang ke Padang dan kembali membawa Nuraini, istri Rustam yang baru saja dikawini dengan jalan berwakil melalui surat.

Kondisi ini membuat rumah tangga Rustam berantakan. Huru-hara tersebut disebabkan oleh sikap Rustam yang lemah terhadap paksaan keinginan bapaknya. Perkawinan tersebut meskipun dengan jalan paksaan, tetapi dengan persetujuan Rustam sendiri. Istri Rustam, Darsina sangat terpukul dengan kondisi tersebut. Rustam sangat sedih dan menyesali perbuatannya, hingga akhirnya dalam keadaan tersebut anaknya meninggal juga karena penyakit. Istri yang sudah dipesan (disetujuinya melalui surat), tidak jadi diterimanya. Nuraini dengan segala pengantarnya terpaksa kembali ke Padang. Akhirnya, Rustam meminta maaf kepada istrinya atas segala kesalahan yang dilakukannya. Segala hal yang berkaitan dengan urusan rumah tangganya diselesaikan dengan orang tua dan istrinya hingga rumah tangga Rustam kembali normal dan bahagia.

Dalam Asmara Jaya, terlihat konsep tema yang sama dengan novel sebelumnya. Secara struktur, formula yang muncul adalah perkawinan, kemauan orang tua, paksaan, latar budaya dan tempat, cinta, dan akhir yang bahagia. Genre yang digunakan merupakan roman karena di dalamnya ada hubungan perkawinan (percintaan) antara dua orang yang berbeda latar budaya, yaitu Minang dan Sunda. Kondisi tersebut sebenarnya tidak berbeda dengan novel pertama, hanya perbedaan mendasar yang muncul terletak pada latar tempat dan situasi yang dialami oleh tokoh utama. Tokoh utama dalam novel ini terlibat prahara rumah tangga karena menerima paksaan keinginan dari orang tua. Tokoh utama dalam Asmara Jaya sudah menikah dan berkeluarga, sedangkan dalam 
novel Darah Muda tokoh utama belum menikah. Alur yang digunakan adalah alur maju dengan akhir bahagia. Alur maju dipahami sebagai konstruksi hubungan sebab akibat yang terjadi dan dialami oleh tokoh cerita secara progresif sehingga fase penceritaan cerita berjalan dari awal hingga akhir.

Permasalahan yang muncul secara mendasar adalah tradisi atau adat. Dalam arti, orang tua masih menjadi penentu dalam memilihkan (memaksakan) jodoh atau pasangan bagi anaknya. Kemunculan persoalan "pemilihan jodoh" tersebut dalam novel Darah Muda dan Asmara Jaya dimaksudkan sebagai tawaran ide perubahan sikap terhadap kebaruan mekanisame menemukan jodoh dan pasangan hidup dalam adat atau tradisi dengan modernitas yang mulai masuk dalam sistem sosial masyarakat. Dalam situasi ini karya sastra menjadi sebuah ruang untuk membangun dialektika terhadap isu-isu yang relevan dan berkembang sehingga genre roman (percintaan) dirasa sebagai satu media yang efektif dalam menyampaikan isu antaretnis yang cenderung mendiskreditkan salah satu pihak tertentu. Cinta menjadi satu bagian yang universal dan dirasa efektif dalam memasuki dan meleburkan sekat-sekat yang kaku dari tradisi ataupun etnisitas. Kesamaan yang muncul dalam kedua karya Adinegoro tersebut adalah akhir yang bahagia. Akhir bahagia ini merupakan salah satu bentuk toleransi yang ditawarkan pengarang secara struktural dalam genre roman antaretnis sebagai negosiasi bahwa cinta lebih esensial menyelesaikan masalah dibandingkan dengan aspek lainnya.

Situasi yang sama juga terjadi dalam novel Tenggelamnya Kapal van Der Wijck (1938) dan Merantau ke Deli (1940) karya Hamka. Kedua novel tersebut juga berpijak pada pertemuan sepasang manusia dalam percintaan beda latar belakang suku. Secara menyeluruh kedua novel itu juga termasuk dalam genre roman. Tenggelamnya Kapal Van der Wijck menceritakan hubungan kisah cinta seorang gadis Minangkabau dengan seorang pemuda Bugis (Sulawesi). Menurut adat Minangkabau, gadis Minangkabau tidak boleh kawin dengan pemuda dari luar, kecuali pemuda atau laki-laki Minangkabau juga. Berikut sinopsis singkatnya.

Kisah cinta dalam novel ini bermula ketika Zainudin, yang lahir di kota Makassar, pergi ke kampung bapaknya, yaitu kota Padang, Sumatera Barat. Zainudin dianggap sebagai anak terbuang. Karena apabila dia berada di Makassar, dia tidak diakui karena bapaknya adalah seorang Minang. Begitu juga apabila dia berada di Sumatera Barat, dia tidak diakui karena ibunya adalah seorang asing dari Makassar. Di kampung halaman bapaknya itu, Zainudin bertemu dengan pujaan hati, Hayati. Akan tetapi, cinta mereka tidak sampai ke pelaminan disebabkan oleh hambatan budaya. Zainudin tidak mendapat izin dari ninik-mamak untuk meminang Hayati yang akan dinikahkan dengan Aziz. Zainudin yang patah hati kemudian diserang penyakit sangat lama. Setelah sembuh, ditemani oleh seorang sahabat, Muluk, mereka kemudian berangkat ke Jawa untuk mengadu nasib. Zainudin kemudian menjadi seorang penulis terkenal dengan letter " $Z$ ". Dia menjadi orang sukses di Jawa dan membentuk "kelompok anak Sumatera". Kemudian, di Jawa itu, dia bertemu lagi dengan Hayati dan Aziz. Akan tetapi, Zainudin telah menjadi orang yang baik budi sehingga dendam dan sakit hatinya telah hilang sama sekali.

Ketika dipecat dari pekerjaan kerena kecerobohan dan kelalaiannya dalam menjalankan perusahaannya, Azis bersama Hayati tinggal di rumah Zainuddin. Namun, Azis merasa tidak kerasan tinggal di rumah Zainuddin karena perlakuan pemuda itu sangat baik terhadap keluarganya. Azis kemudian memutuskan untuk meninggalkan Hayati di rumah Zainuddin dan pergi entah ke mana. Tak berapa lama kemudian, Azis mengirimkan dua pucuk surat, yaitu surat pertama ditujukan kepada Hayati yang isinya hendak menceraikannya, dan surat kedua ditujukan kepada Zainuddin yang isinya meminta untuk menikahi Hayati. Surat itu merupakan pesan terakhir darinya karena tak lama kemudian Azis meninggal dunia. 
Azis kemudian menyerahkan dan mengamanahkan Hayati kepada Zainudin. Namun, Zainudin tidak berpikiran demikian. Dia malah mengirim pulang Hayati ke kampung halaman di Sumatera Barat dengan kapal Van der Wijck. Karena kuasa Allah, kapal mengalami kecelakaan. Zainudin yang sesungguhnya masih memiliki cinta kepada Hayati, merasa bersalah. Kemudian dia menyusul Hayati ke tempat posko penyelamatan dan ditemuinya Hayati dalam keadaan sekarat. Namun, mereka masih sempat bertatap muka dan saling meminta maaf akan kesetiaan cinta. Cinta Zainudin dan Hayati dipersatukan kembali, tetapi tidak diridhai oleh takdir. Hayati meninggal dengan menyebut dua kalimat syahadat. Sepeninggal Hayati, Zainudin membuat karya terakhirnya, dan setelah itu dia terkena penyakit yang menyebabkan dia meninggal pula, kemudian dia dikuburkan di sebelah kuburan Hayati.

Genre novel di atas menunjukkan bagaimana sepasang manusia mengalami percintaannya hingga meninggal dunia. Kisah tersebut merupakan genre roman dengan formula yang agak berlainan dengan karangan Adinegoro meskipun keseluruhan strukturnya memiliki pola yang sama. Tema yang diangkat juga sama, kisah percintaan dua manusia dengan latar belakang etnis berbeda, yaitu Padang (Minang) dengan Makassar (Bugis). Perbedaan terletak pada komposisi formula yang berakhir dengan sedih. Selain itu, unsur-unsur yang muncul adalah perkawinan, aturan adat atau hambatan budaya, patah hati, persetujuan orang tua, status, latar belakang suku, kehilangan pekerjaan, musibah, dan kematian.

Dari aspek formula yang muncul di atas, tokoh utama berada dalam situasi yang kurang baik (tragis). Kondisi hidup sebagai sebuah kendala yang merintangi, sistem norma adat, status, dan juga faktor-faktor eksternal di luar tokoh menjadi komposisi struktur cerita secara kuat. Formulasi cerita tersebut membedakan dengan dua karya novel sebelumnya, yang secara kompleksitas mempunyai struktur cerita lebih banyak. Perbedaan perkembangan dari kedua novel sebelumnya terlihat dari peristiwa-peristiwa yang dialami oleh tokoh utama. Kondisi psikologis mereka terpaksa menerima keputusan nasib dan adat sebagai sebuah kekalahan dalam percintaan. Perkembangan yang terjadi dalam novel ini adalah munculnya tambahan pola-pola psikologis yang dialami oleh tokoh utama (patah hati, depresi, disorientasi, kehilangan keyakinan). Pola psikologis tersebut muncul dalam rangka memberikan tekanan "emosi" kepada pembaca agar ikut terharu dan masuk dalam alur cerita secara keseluruhan.

Hamka menekankan struktur cerita percintaan sebagai sebuah media negosiasi dalam merumuskan keberlangsungan hubungan beda etnis. Pengertian yang muncul adalah etnisitas sebagai bagian dari karakter budaya menjadi pedoman yang tidak mudah dilepaskan oleh seseorang dari komunitasnya. Hal tersebut juga muncul dalam karya Adinegoro pada pembahasan sebelumnya. Roman Tenggelamnya Kapal Van der Wijck menjadi sebuah simbol bagaimana karya sastra mampu menjadi ruang kontemplasi dalam melihat persoalan etnisitas dalam relasinya dengan berbagai persoalan yang esensial, yaitu cinta.

Selanjutnya, dalam novel Merantau ke Deli, Hamka mencoba menyampaikan pesan nasionalisme Indonesia melalui hubungan perkawinan antaretnis. Ini dapat dilihat dalam hubungan perkawinan antarentnis yang cukup mencolok antara tokoh Poniem (Jawa) dan Leman (Minangkabau). Hubungan kedua tokoh dari etnis yang berbeda ini sangat menentukan alur cerita novel ini. Latar tempat novel ini adalah daerah Deli dan Medan pada zaman sebelum perang. Leman adalah salah seorang perantau Minang yang mengadu nasib di daerah Deli yang sedang berkembang karena dibukanya onderneming-onderneming tembakau oleh Belanda. Dan Poniem adalah buruh dari Jawa yang datang ke Deli karena hal yang sama: berkembangnya ekonomi Deli akibat pembukaan ondernemingonderneming perkebunan besar di daerah itu. Dalam novel Merantau ke Deli, Hamka jelas sekali mengkritik eksklusivisme perkawinan Minangkabau yang telah menjadi adat dan 
tradisi. Berikut ini sinopsis cerita singkat novel Merantau ke Deli.

Poniem diselamatkan dari lembah kehinaan oleh seorang lelaki bujang, Leman. Kemudian, ia diperisteri dan hidup dalam sebuah rumah tangga yang bahagia. Poniem sangat setia terhadap suaminya dan berusaha sekuat tenaga untuk membantu semua urusan rumah tangga dan pekerjaan suaminya. Akan tetapi, lama-kelamaan kedamaian rumah tangga mereka makin hari makin hilang setelah Leman larut dalam kegiatan perdagangannya. Sebagai lelaki yang berasal dari keluarga Minang, dia ditekan oleh keluarga supaya mengawini seorang gadis yang sederajat untuk meneruskan adat dan budaya.

Lama-kelamaan Leman termakan bujukan tersebut dan menerima untuk menikah kembali. Leman berjanji kepada Poniem tidak akan mengabaikannya dan selalu menjaga perasaannya sebagai isteri pertama. Namun, janji tinggal janji. Isteri mudanya jauh lebih pandai berdandan, merayu, dan merebut perhatian Leman supaya lebih mencintainya. Pertengkaran pun mulai terjadi. Perdagangan Leman yang selama ini dibantu Poniem pun hendak dikuasai oleh isteri muda. Leman yang serba salah lamakelamaan mulai memihak kepada isteri mudanya. Pertengkaran hebat yang terjadi memaksa Leman menceraikan Poniem. Sejak hari itu Poniem meninggalkan rumah dan merantau ke Deli. Kegiatan perdagangan Leman mulai mengalami rugi, ditambah lagi dengan sikap tamak isteri yang baru. Barulah Leman menyadari bahwa selama ini dia banyak terbantu oleh ketekunan Poniem dalam berdagang. Tapi semua sudah terlanjur terjadi.

Poniem akhirnya menemukan jodoh barunya yang lebih memahami dan menghargainya, Suyono - salah satu pekerja di kedai Leman. Mereka memulai berdagang kembali dengan sedikit modal yang ada pada mereka. Usaha dagang mereka maju hingga mereka sanggup membeli rumah dan tanah. Sementara itu, Leman dan isteri mudanya makin hari makin jatuh miskin. Pertemuan kembali Leman dan Poniem terjadi ketika
Poniem dan Suyono telah membeli rumah di Deli. Leman meminta maaf kepada Poniem atas kesalahannya dulu. Dengan lapang hati Poniem memaafkan kesalahan mantan suaminya itu.

Pada cerita Merantau ke Deli tersebut formula yang muncul dalam struktur cerita secara umum masih sama dengan novel Tenggelamnya Kapal Van der Wijck. Hamka mengangkat tema kehidupan sosial dalam hubungan dua insan manusia dengan latar belakang berbeda yaitu, Poniem (Jawa) dengan Leman (Minangkabau). Kisah percintaan yang muncul berakhir dengan tidak bahagia (sad ending). Perkawinan sebagai media menyatukan dua latar belakang yang dicita-citakan gagal karena perubahan pendirian dan pengaruh adat. Kondisi tersebut bisa dilihat dalam formula yang muncul, kemiskinan, tuntutan hidup, meneruskan adat, poligami, perceraian, menikah lagi, dan pemberontakan terhadap adat yang gagal. Adat dalam Merantau ke Deli digambarkan sangat kuat menekan hubungan antara dua manusia yang berlainan latar belakang sehingga perkawinan Poniem-Leman mengalami perceraian.

Jika dibandingkan secara struktural, antara novel Darah Muda dan Asmara Jaya karya Adinegoro dan novel Tenggelamnya Kapal Van der Wijck dan Merantau ke Deli karya Hamka terdapat persamaan genre meskipun dalam konteks tersebut Hamka mengakhiri roman-romannya tersebut dengan akhir yang sedih atau tragis. Apa yang dicitacitakan oleh tokoh-tokoh utama dalam novel tersebut tidak berjalan sesuai dengan harapan. Adapun dalam karya-karya Adinegoro, para tokohnya memenangkan pergulatan dengan perjuangan yang secara tematis, merupakan benturan atas pemberontakan terhadap adatistiadat.

Etnisitas masih menjadi tema yang menarik sebagai "bumbu" formula dalam roman pada dua periode awal sastra Indonesia modern antara tahun 1920-an sampai periode 1940-an akhir. Kesadaran dalam mengangkat isu antaretnis tersebut merupakan wacana yang secara struktur berpijak dari kondisi kesukuan di Indonesia yang plural dan 
majemuk. Meskipun antara Nurdin-Rukmini (Minangkabau-Sunda); Rustam-Dirsina (Minangkabau-Sunda); Zainudin-Hayati (Makassar-Minangkabau); dan PoniemLeman (Jawa-Minangkabau) kesemuanya hidup dalam konteks dan ruang berbeda, secara genre mampu disatukan ke dalam satu benang merah yang sama, yakni persoalan antaretnis. Persoalan tersebut dikemas dalam tema yang menarik untuk disimak, yaitu melalui percintaan. Bagaimana perspektif cinta antara kaum muda dan perspektif kaum tua dalam meneruskan tradisi (adat-istiadat), masing-masing mempunyai alasan.

Cemooh kaum muda terhadap anggapan cinta yang utopis dari para orang tua kadang beralasan pula. Tidak jarang golongan tua menghinakan percintaan dan hanya mengingat harta benda keturunan bakal lahir menantunya. Anak mereka dipaksakan menikah dengan alasan tradisi atau adat, keturunan, maupun harta. Permasalahan lain yang muncul dalam roman-roman tersebut adalah anggapan atau posisi pengarang (ideologis) dalam roman sangat berpengaruh dalam menentukan bentuk serta nasib para tokoh-tokohnya. Dalam pengungkapan keberpihakan (amanat) pengarang tentang persoalan percintaan antara golongan tua dan muda, masing-masing pihak saling menyudutkan dan menyalahkan satu sama lain. Dalam posisi tersebut, formulasi yang dilihat sebagai bagian dalam penentuan genre roman adalah komposisi strukturnya. Bukan sekadar melihat kedangkalan segi cerita roman, tetapi juga bagaimana perhatian pengarang terhadap berbagai fenomena persoalan tersebut dalam konteks ruang dan waktunya di masyarakat.

Meskipun secara umum penulis roman yang mengangkat isu antaretnis pada periode tersebut lebih menyoroti perbedaan kultural yang ada dan bersinggungan dengan tradisi Minangkabau (Sumatra Barat), bisa disimpulkan secara sekilas bahwa Minangkabau mempunyai peranan penting dalam membangun dialektika kesukuan di Indonesia. Melalui para pengarang baik yang lahir dan berasal dari Minangkabau, maupun bukan, interkultural dan antaretnis Indonesia disajikan dalam kisah-kisah percintaan manusia. Popularitas genre roman selalu didasari dengan berbagai aspek yang mendukungnya, yaitu pekerjaan, percintaan, orang tua, adat, nasib, psikologis, latar, konteks sosial budaya, dan juga akhir cerita.

Genre roman selanjutnya yang membahas perkawinan dengan "bumbu" beda agama terdapat dalam novel Keluarga Permana karya Ramadhan K.H. (1978) dan Orang Buangan karya Harijadi S. Hartowardoyo (1971). Kedua novel tersebut melihat hubungan pasangan yang berlainan keyakinan, dalam Keluarga Permana antara tokoh Ida (Islam) dan Sumarto (Katolik), sedangkan dalam Orang Buangan antara tokoh Tantri (Islam) dan Hiang Nio (Katolik). Hubungan antaragama menjadi satu hal yang memicu isu SARA dalam pluralitas masyarakat Indonesia. Sampai saat ini, agama merupakan ruang yang intoleran dalam menerima percampuran dua keyakinan karena mengaburkan identitas dan hubungan religiusitas para pemeluknya. Wilayah ini masih sangat kurang dieksplorasi dalam khazanah kesusastraan Indonesia modern karena selalu menjadi arena yang rawan salah penafsiran. Kondisi tersebut dipahami oleh para pengarang untuk tidak mengambil tema atau isu agama karena bisa menimbulkan sesuatu efek chaos antaragama.

Novel Keluarga Permana karya Ramadhan K.H merupakan salah satu novel yang fenomenal dan kontroversial. Novel ini mampu mencerminkan kehidupan masyarakat Indonesia modern dan kesadaran pengarangnya mengenai masalah yang dihadapi, yaitu masalah sosial keagamaan. Keluarga Permana memenuhi kriteria karya sastra sebagai potret indah yang menggambarkan masyarakat, bahkan analisis kehidupan sosial dengan segala perubahan masyarakat di dalamnya. Berikut sekilas sinopsis cerita Keluarga Permana.

Permana yang dulunya terkenal bijaksana, sikapnya berubah drastis ketika dirinya diberhentikan dari tempat kerja dengan alasan yang tidak jelas. Keluarga Permana yang sebelumnya demikian damai dan tentram, tiba-tiba berubah suasana, penuh 
dengan penderitaan, baik lahir maupun batin. Pemecatan itu membuat Permana menjadi seorang kepala keluarga yang kasar. Suka menyiksa anak dan istrinya dengan alasan yang terkadang dibuat-buat. Atau dengan kesalahan yang tak sewajarnya sampai mendapat hukuman yang berat. Walaupun kesalahan itu adalah kesalahan Permana, tetap saja istri dan anaknya yang mendapat siksaan. Bahkan, pukulan lidi bukan hal yang asing lagi bagi anak dan istrinya

Selama Permana tidak bekerja lagi, istrinyalah yang bekerja keras mencari nafkah. Saleha-lah yang bekerja untuk mencukupi kebutuhan harian keluarga itu. Namun, walaupun sudah bekerja keras, istrinya tetap saja mengalami siksaan dari suaminya. Hal ini sebenarnya disebabkan oleh Permana merasa dirinya tidak berarti sebagai seorang laki-laki. Dia merasa malu sehingga otak jernihnya menjadi buram, penuh dengan prasangka yang dibuat-buat saja. Dalam benaknya sering terbayang bahwa istrinya sewaktu bekerja pasti disenangi oleh kaum laki-laki di tempat kerjanya. Apalagi ketika Saleha pulang dengan diantarkan oleh manajernya, makin buruk prasangka Permana. Permana suka cemburu yang tanpa bukti.

Pada bagian lain, Sumarto menumpang (indekos) di rumah Permana. Sumarto menebar benih cinta kepada Ida. Ida pun mulai jatuh cinta kepada Sumarto. Kemudian Sumarto mulai menggauli Ida. Permana curiga atas keintiman Sumarto dan Ida. Permana mengusir Sumarto dari rumahnya. Ida hamil buah hubungannya dengan Sumarto. Permana dan Saleha sepakat menggugurkan kandungan Ida. Kandungan Ida gugur oleh ramuan racun dari dukun sehingga Ida dilarikan ke rumah sakit. Sumarto menyesali perbuatannya, Pastor Mordiyono menyarankan Sumarto untuk mengawini Ida. Permana dengan berat menyetujui Ida kawin dengan Sumarto. Ida dibaptis menjadi Katolik dengan perasaan terpaksa. Perkawinan Ida dengan Sumarto menimbulkan konflik. Mang Ibrahim marah merasa kehilangan cucunya yang kini menjadi Katolik. Akhirnya, Ida meninggal di rumah sakit. Sebelum meninggal, suster rumah sakit membisikkan kalimat syahadat. Ida pun mengikuti kalimat syahadat yang diucapkan oleh suster tersebut dengan lancar. Suster tersebut kaget saat mengetahui bahwa suami Ida seorang Katolik.

Mendengar berita kematian Ida, Saleha dan Permana sangatlah terpukul. Kedua orang suami istri itu teruslah menyalahkan diri mereka sendiri. Setelah jenazah diberangkatkan ke rumah orang tua Ida, terjadi sedikit konflik yang dialami Permana dan Saleha. Keduanya sebenarnya menghendaki membumikan ida di permakaman muslim. Akan tetapi, pada kenyataannya setelah jenazah itu sampai, Ida diputuskan untuk dimakamkan di tempat penguburan Katolik karena mengikuti keluarga Sumarto. Apalagi saat itu Ida telah dibaptis dan masuk ke dalam ajaran Katolik meskipun tidak tahu apa yang ada di hati Ida sendiri. Semua itu didasarkan pada terpaksa. Permana yang dulunya arogan kini makin rapuh. Permana merasa sangat bersalah kepada Ida sehingga dia terus menunggui tanah makam Ida sepanjang hari tak merasa panas dan hujan. Kini Permana makin tidak waras. Permana hanya bisa meratapi kesalahan-kesalahannya yang lalu.

Struktur cerita menggambarkan isu tema umum, yaitu antaragama. Keluarga Permana disebut sebagai novel fenomenal hingga saat ini karena mencerminkan potret kehidupan antarumat beragama di Indonesia, di tengah pluralitas dan heterogenitas mayarakat Indonesia yang multiagama. Secara genre novel tersebut termasuk ke dalam jenis roman yang melibatkan percintaan tokoh utama Ida (Islam) dengan Sumarto (Katolik). Percintaan keduanya sebenarnya tidak direstui, tetapi pada akhirnya disetujui dengan terpaksa oleh orang tua Ida. Hingga pada akhirnya pernikahan mereka berakhir tragis dengan kematian Ida. Formula yang menyusun struktur cerita adalah pemecatan, ekonomi, percintaan Ida dan Sumarto, konflik, aborsi, pindah agama, pernikahan, sakit keras, dan meninggal dunia. Permasalahan dalam Keluarga Permana adalah dimensi sosial keagamaan, yaitu menyangkut perikehidupan antarumat beragama, yakni perpindahan 
agama dan konflik-konflik sosial keagamaan yang ditimbulkannya.

Pada Orang Buangan, Tantri harus berada dalam situasi psikologis yang membingungkan karena perasaan cintanya kepada Hiang Nio, seorang Katolik keturunan Tionghoa. Perbedaan kemauan dari orang tua Hiang Nio, tata cara menikah, peraturan perundangan atau hukum menikah beda agama menjadi satu persoalan yang dilematis bagi Tantri. Hiang Nio sepenuh hati mencintai Tantri dan mau menerima apa pun keadaan Tantri. Berikut ini sinopsis novel Orang Buangan.

Tantri merupakan seorang guru sekolah rakyat di daerah terpencil. Tantri terikat kontrak selama lima tahun dengan Jawatan (Dinas) Pengajaran di desa tersebut. Ia sekaligus juga sebagai kepala sekolah di desa terpencil yang ditunjuk dari jawatan tersebut. Tantri sebenarnya adalah seorang mahasiswa jurusan kedokteran yang cuti kuliah karena keterbatasan biaya. Di desa tersebut Tantri terkenal sebagai seorang guru yang ramah, rajin, cerdas, dan disayang oleh murid-muridnya. Prestasi dan dedikasi Tantri terhadap sekolah dan tugasnya menunjukkan kinerja yang luar biasa sehingga selalu dipujipuji oleh Pak Lurah dan juga Pak Camat. Hal tersebut menimbulkan kecemburuan dari guru-guru lain.

Suatu ketika Tantri pergi ke kota mengambil gaji para guru selama tiga hari. Selama kepergiannya tersebut, Idjah salah satu kembang desa yang juga murid Tantri, dinikahkan dengan Djolodong, seorang lelaki kampung yang juga lintah darat. Pernikahan Idjah dengan Djodolong tersebut karena paksaan. Djolodong sudah lama menaruh hati pada Idjah, sedangkan Idjah menyukai Tantri. Orang tua Idjah, Pak Truno terpaksa menikahkan anaknya dengan Djolodong karena sudah berutang budi dan tidak bisa menolaknya. Namun, dalam penikahan tersebut tiba-tiba terjadi peristiwa menggemparkan kampung. Pengantin pria, Djolodong, mendadak meninggal dunia. Penduduk kampung menduga ini semua adalah akibat dari ilmu gaib yang dimiliki oleh Tantri. Selanjutnya, Kyai Kasan Djamil, dukun kampung mencoba melakukan pengobatan dengan mengatakan bahwa ada kekuatan gaib yang menyebabkan semua hal tersebut.

Esoknya ketika Tantri kembali ke kampung, suasana sudah tegang. Orang-orang sibuk memperbincangkan peristiwa semalam. Tantri menjadi bahan perbincangan. Meninggalnya Djolodong mengundang berbagai desas-desus dan isu yang muncul dalam masyarakat. Setelah peristiwa tersebut, tanpa diduga kematian-kematian beruntun terus menyerang warga kampung, termasuk kakak kandung Djolodong, Djendol. Orangorang panik dan ketakutan, mereka menduga kondisi tersebut dikaitkan dengan guna-guna yang dilakukan oleh Tantri.. Ia menduga kematian adik Djolodong adalah ulah Tantri karena selama ini Tantri dekat dengan keluarga Idjah. Tantri sering datang ke rumahnya dan mengajari Idjah. Tantri menduga hal tersebut merupakan wabah. Korban berjatuhan dan kondisi kampung makin mencekam. Tantri teringat Hiang Nio, perempuan keturunan Tionghoa yang dicintainya. Cinta mereka tersekat batas agama dan orang tua. Hiang Nio beragama Katolik, sedangkan Tantri Islam. Pernikahan beda agama belum diatur dalam perundangan, dan prosesnya rumit.

Pak Lurah dan Pak Camat meminta laporan kejadian yang menimpa desa tersebut kepada Tantri. Tantri menyarankan agar membuat laporan adanya wabah sehingga mendapat penangangan tepat dari Dinas Kesehatan. Akhirnya, dikirimkanlah beberapa tenaga medis dan perawat untuk melakukan pencegahan dan observasi atas keadaan yang terjadi di desa tersebut. Tanpa disengaja, Tantri bertemu dengan kekasihnya, Hiang Nio, setelah sekian lama tidak bertemu dan hubungan mereka menggantung. Hiang Nio adalah seorang dokter yang kebetulan ditugaskan untuk membantu menanggulangi wabah di desa tersebut. Tantri kaget sekaligus senang. Ia kembali bertemu dengan orang yang dicintainya. Namun, ia kembali harus menghadapi fitnah dan tuduhan bahwa dirinya adalah seorang dukun munafik yang menyamar sebagai guru sekolah. Tuduhan 
yang ditujukan oleh partai di kampung tersebut dan masyarakat membuat Tantri dikucilkan.

Idjah mencintai Tantri. Kondisi tersebut diketahui oleh Hiang Nio yang juga masih mencintai Tantri. Idjah cemburu dan histeris melihat Tantri dekat dengan Hiang Nio. Ia tidak mau dipisahkan dengan Tantri. Namun, Tantri memilih rasa cintanya pada Hiang Nio yang selama ini masih setia menunggu Tantri. Hiang Nio menceritakan bahwa orang tuanya sudah ikhlas menerima kondisi Tantri, tanpa suatu syarat apa pun. Akhirnya, mereka berdua memutuskan untuk menikah, memperjuangkan cintanya melebihi batas dan sekat agama.

Persoalan yang menarik dan muncul dalam Orang Buangan tidak semata-mata mendeskripsikan hubungan percintaan antaragama, tetapi juga antaretnis. Bagaimana posisi kesukuan juga dijadikan tema saat melihat hubungan pribumi dengan etnis lain, khususnya Tionghoa (Cina). Cina digambarkan dengan sesuatu yang lain dan berbeda dalam segala latar belakang. Kompleksitas hubungan tersebut juga menjadi fenomena ketika melihat ruang yang ada di balik sekat agama dan sekat etnis. Secara kultural, Tionghoa (Cina) masih diasumsikan sebagai pendatang, bukan suku asli dalam pluralitas kehidupan di Indonesia. Latar belakang sosial kultural dalam novel ini diangkat sebagai sebuah permasalahan yang mencuat. Tema besar yang muncul di baliknya adalah sebuah persoalan struktural klasik, yaitu antara pandangan tradisional dengan pandangan modern. Struktur tersebut membangun formula dalam novel dengan kisah percintaan beda agama dan beda etnis. Adat, keturunan, moral, hukum, agama, keyakinan, kedudukan, dan prinsip hidup menjadi bagian yang tradisional. Sementara itu, cinta, kemauan, semangat, kenyataan, dan kebahagiaan merupakan wilayah modern yang disimbolkan sebagai kaum muda.

Persinggungan agama dalam novel tersebut secara garis besar mirip dengan novel Keluarga Permana meskipun komposisi formula ceritanya berlainan. Relasi Islam dengan Katolik membawa gagasan universal terhadap persoalan esensi kemanusiaan yang lebih utama daripada keagamaan. Percintaan menjadi wilayah logis-empiris lebih cair dalam menemukan keterkaitan dan celah yang sempit di antara ruang agama dan etnisitas. Individu yang berlainan bertemu dalam kerangka "cinta" sebagai sebuah ekspresi yang esensial dan hakiki. Cinta menembus ruangan yang selama ini dipenuhi dengan isu SARA, tabu, sensitif dalam menjelaskan siapa sebenarnya manusia di hadapan struktur tersebut. Tantri dan Hiang Nio menemukan jalan menuju "ruang" pertemuan internal mereka, yang tidak dipahami dan terjangkau oleh konsep agama. Regulasi-regulasi sosial yang berlainan konsep norma, secara kasat mata menjadikan gagasan tentang perbedaan lebih sulit diterima secara utuh.

Formulasi roman dalam novel-novel tersebut menggabungkan sebuah gagasan sentral tentang manusia sebagai dirinya pribadi, dalam menemukan eksistensi dan kebermaknaan hidup. Pilihan-pilihan secara psikologis dimaksudkan ikut mempertegas dan memperkokoh sikap serta karakter manusia, sebagai tokoh yang hidup dalam segala persoalannya. Secara struktur, formulasi yang muncul dalam novel Orang Buangan adalah kondisi psikologis, intelektualitas, lokalitas, percintaan, wabah, fitnah, perbedaan adat dan latar belakang agama, serta pernikahan beda agama.

Harijadi S. Hartowardoyo secara sadar menemukan fenomena agama dan etnisistas sebagai arena yang menarik dalam struktur bangunan cerita. Komposisi dan struktur cerita tersebut disajikan sebagai konstruksikonstruksi tanda dan makna agar pembaca menemukan sikap pengarang (amanat). Dalam hal ini, pengarang menunjukkan sikapnya yang tidak mendiskreditkan atau memojokkan salah satu aspek (baik etnis maupun agama) dalam struktur masyarakat. Namun, pengarang menawarkan solusi dalam kerangka sistem perundangan yang mengatur hak warga negara dalam pernikahan perjanjian perdata, bukan dalam kerangka hukum agama. Komposisi roman tersebut menjadi wacana implisit bagaimana hubungan antara adat, norma, agama, intelektualitas, dan 
juga humanitas disejajarkan dalam relasi yang seimbang. Kesimpulan sikap pengarang terlihat dalam kemenangan tokoh utama, yaitu Tantri-Hiang Nio, yang menemukan masa depan mereka melalui cinta yang meleburkan segala ruang etnis dan agama.

\section{Kesimpulan}

Genre dalam karya sastra bisa ditentukan dengan formulasi alur dan juga strukturstruktur pelengkapnya. Dalam penelitian sederhana ini, yang menjadi permasalahan adalah perbandingan genre antara beberapa periode (tiga periode novel). Aspek yang bisa disimpulkan dalam analisis genre novel adalah formulasi dan juga struktur dari masing-masing karya tersebut mengandung benang merah yang saling berkaitan.

Novel-novel yang dianalisis mempunyai kesamaan genre yaitu, roman (kisah percintaan sepasang manusia). Meskipun formulasi dalam struktur novelnovel tersebut antara satu dan yang lain dibumbui dengan bermacam pola yang beragam, kesemuanya berkaitan dengan tema mendasar, yaitu antaretnis dan antaragama. Formulasi mendasar ini menjadi faktor tambahan dalam melihat kecenderungan dan perubahan pola yang ada dari ketiga periode novel-novel bergenre roman tersebut. Persoalan teknis yang muncul dalam novelnovel tersebut adalah perbedaan kecenderungan penyelesaian masalah dari masing-masing periode dan pengarang. Sebagian karya mengalami kegagalan karena menggunakan komposisi dan tema yang sudah klise, terutama roman-roman yang menyuguhkan alur dengan akhir bahagia (happy ending).

Isu primordialisme dan lintas agama adalah bagian yang penting dalam rangka memahami dan mengapresiasi identitas keIndonesia-an mutakhir, yang melekat dalam bermacam sekat-sekat budaya. Fenomena ini menjadi satu isu yang krusial ketika melihat sastra Indonesia sebagai sebuah rumah bagi segala wacana dan persoalan identitas yang terus- menerus berlangsung. Kemajemukan masyarakat secara sosial dan kultural/budaya, mengarahkan pembentukan toleransi dalam rangka menemukan jawaban-jawaban persoalan maupun ideologi yang terkandung dalam teks. Jika ditarik kepada konsep pascakolonialisme, identitas bukan sekadar sesuatu yang baku (beku), melainkan sudah menjadi cair. Seiring dengan perubahan dan orientasi dalam menciptakan semangat kebersamaan, agama dan kesukuan bukan lagi dilihat sebagai sesuatu yang absolut mengikat dalam menciptakan disintegrasi. Agama dan kesukuan merupakan fenomena yang menjadi dasar untuk mengembalikan pemikiranpemikiran primordial ke arah yang lebih terbuka. Isu antaretnis dan antaragama masih relevan dilihat sampai saat ini sebagai sebuah cara pengarang menentukan sikap terhadap pluralitas atau kejamakan budaya dan keyakinan yang memperkaya negeri ini.

\section{Daftar Pustaka}

Adi, Ida Rochani. 2011. Fiksi Populer: Teori dan Kajian Metode. Yogyakarta: Pustaka Pelajar.

Adinegoro, Djamaluddin. 1927. Darah Muda. Jakarta: Balai Pustaka.

Pustaka.

Hamka. 1940. Merantau ke Deli. Jakarta: Jayabakti.

--------. 1938. Tenggelamnya Kapal Van Der Wicjk. Jakarta: PT Bulan Bintang.

Hartowardojo, Harijadi S. 1971. Orang Buangan. Jakarta: Pustaka Jaya.

Kartahadimaja, Ramadhan. 1978. Keluarga Permana. Jakarta: Dunia Pustaka Jaya.

Wellek, Rene \& Austin Warren. 1995. Teori Kesusastraan. Diterjemahkan oleh Melani Budianta. Jakarta: Gramedia. 